\title{
The Importance of Religiousity and Resilience on Z-Generation and the Implication for School Counseling
}

\author{
Kusnarto Kurniawan ${ }^{*}$, Eem Munawaroh ${ }^{2}$, Binti Isrofin ${ }^{3}$ \\ 1,2,3 Guidance and Counseling, Universitas Negeri Semarang, Indonesia
}

\begin{abstract}
The youngest generation needs to possess psychological resilience to deal with the Industry 5.0 challenge. Therefore, it is important to determine the contributing factors responsible for z-generation resilience. The purpose of this study is to examine the correlation between religiousity and resilience on z-generation. Data were obtained from 455 college students of Universitas Negeri Semarang, Indonesia. The Centrality of Religiosity Scale (CRS), developed by Huber, was used to determine the five aspects of religiosity, namely intellectual dimensions, ideology, public and private practice, as well as a religious experience. Meanwhile, the Brief Resilience Scale developed by Smith, Dalen, Wiggins, Tooley, Christopher, and Bernard (2008) was used to measure resilience. The result showed that religiousness significantly correlated to the resilience of the z-generation.
\end{abstract}

Keywords

Religiosity; Resilience; Z generation

Article Received: 20 September 2020, Revised: 30 November 2020, Accepted: 18 December 2020

\section{Introduction}

The z-generation is characterized by the high use of internet connection, technology communication, and prolific use of social media (Gaidhani, Arora, \& Sharma, 2019). According to a demographic survey, $34,05 \%$ of the world's population are z-generation, and this number is likely to increase by approximately $40 \%$ in 2050 . The Indonesian millenial generation profile showed that $29.23 \%$ of the country's population was born from 1995-2010 (z-generation), and after the y-generation (1980-1995) (Profil generasi milenial Indonesia (2018), and (Putra, 2016)).

In some studies, the z-generation was referred to as a native digital, because they were born after the internet. However, there are unique differences associated with each generation. Lancaster \& Stillman Putra (Putra, 2016) stated that the $\mathrm{X}$ and millennial generations differ in work habits. The $\mathrm{x}$-generation shows diversity in thinking, balancing work with life, and relying on oneself, while Millennials have a high sense of optimism, focus on achievement, confidence, with belief in moral and social values.

Researchers around the world have investigated the characteristic of the z-generation in accordance with various purposes such as labour, study, and marketing. Tari (Csobanka, 2016) defined them as follows 1) lack strong family relationships as opposed to previous generation 2) smart, with underdeveloped emotional intelligence. They are unable to process understandable information emotionally 3) live a happier life with less value 4) The opinion of peers is overrated, and most times, it is essential. 5) New ways of partnerships and sexuality appear. The z-generations are those born after the 1995 struggle with several significant problems. Novkovska \& Serafimovic (Novkovska \& Serafimovic, 2018) portrayed them as those vulnerable to becoming poor and socially excluded from society because they spend a significant amount of time out of education and work training. Furthermore, they are more likely to engage in mental health problems such as bullying. Shalleh, Mahbob, \& Baharuddin (Salleh, Mahbob, \& Baharudin, 2017) on their study on "Me Generation" stated that less sense of belonging, responsibility, and awareness are contributing factors to the increase of maintenance cost in on-campus residencies. Economics hardship shaped Indonesian z-generation, 49\% stated that they prefer a job with a stable income, and $79 \%$ said that job security was important (Dwidienawati \& Gandasari, 2018). These facts placed them into high risk of stress and depression.

Religiousity is changed in every generation. In the United States, 78\%, 70\%, and 56\% of the Baby Boomers, $\mathrm{x}$-generation, and z-generation were 
identified as Christians (Chase, 2016). The statistical data shows that the younger the generation, the lower the religiousity percentage. According to Salquist, Eisenbergh, France, Purwono, and Suryanti (Sallquist, Eisenberg, French, Purwono, \& Suryanti, 2010), religiousity is a person's attachment to certain religions and organizations. System of beliefs, values, rituals, and practices commonly shared by a social community as a means of connecting with God.

Religiousity contributes to a more positive life for the younger generation and helps them to achieve success during adolescence. Furthermore, it is linked to mental and physical health functioning, as well as increased longevity (Nooney \& Woodrum, 2002; Powell, Shahabi, \& Thoresen, 2003) (Oxman, Freeman, \& Manheimer, 1995). The high level of personal religiousity is related to low-risk behaviors such as drug abuse. Therefore, engaging in various religious activities strengthens social networks, relationships with family and friends, and provides life satisfaction. Smith, Webber, and DeFrain (L. Smith, Webber, \& DeFrain, 2013) stated that religious people are happier and tend to quickly recover from misfortunes and crisis than those that are nonreligious. This proves that religiousity is related to the resilience of the individual.

The results of various studies on the characteristics of $\mathrm{Z}$ generation shows that they need higher self-resilience because the challenges faced are more complex. These challenges stem from rapid technology, family constellations, and social changes. They are raised amidst turbulence and economic insecurity. In addition, the emergence of Covid-19 has strengthened their point of view on the dangers associated with living on this planet. Furthermore, they suffer from mental health disorders with the spread of bullying on social media and other smartphone applications (Merriman, 2015).

Sikorska (2017) defined resilience as a form of successful adaptation and development in risky or disadvantageous situations. The development of resilience in the younger generation is the result of interactions between personality and personal characteristics with the support of systems, communities, and mental health (Ahern (L. Smith, et al., 2013)). Several studies have been conducted to examine the relationship between religiosity and resilience. Javanmard (Javanmard, 2013), in research on religious beliefs and resilience in academic students, reported that function based on religious beliefs is related to resilience and acts as predictor variables. Rahmati et al. (Rahmati, Khaledi, Salari, Bazrafshan, \& Haydarian, 2017) stated the significant effectiveness of spiritual and religious interventions in increasing the resilience of family members of patients.

Stavrianea \& Kamenidou (Stavrianea \& Kamenidou, 2017), on their research related to the role of religiosity on $\mathrm{Z}$ generation in times of crisis, proved that the church has become a protective shelter. A total of 115 respondents revealed that churches fulfill the need for emotional and social support in a hazardous environment.

The purpose of this study is to examine the relationship between religiousity and the resilience of college students. This research is significant in understanding how religiousity and resilience influence z-generation. The hypothesis showed that resilience and religiousity correlated with the z-generation during school counseling practice. This research implies that there are resilience and religiosity factors that are beneficial to the $\mathrm{Z}$ generation.

\section{Method}

This is a correlational research use to investigate the relationship between religiousity and resilience. Data were randomly obtained from 455 students of Universitas Negeri Semarang, West Java, Indonesia, between the ages of 18-22. The Centrality of Religiosity Scale (CRS), developed by Huber, was used to determine the five aspects of religiosity, namely intellectual dimensions, ideology, public and private practice, as well as a religious experience. Meanwhile, the Brief Resilience Scale developed by Smith, Dalen, Wiggins, Tooley, Christopher, and Bernard (B. W. Smith et al., 2008) was used to measure resilience. The data analysis used in this study is the productmoment. 


\section{Finding}

Table 1. Shows the result of the correlation of religiousity and resilience on Z-generation

\begin{tabular}{lll}
\hline & & Religiousity \\
\hline Religiousity & Pearson Correlation & 1 \\
& Sig. (2-tailed) & \\
Resilience & Pearson Correlation & 455 \\
& Sig. (2-tailed) &, $473^{* *}$ \\
& N & 4000 \\
\hline
\end{tabular}

The results showed that the correlation coefficient between religiousity $(\mathrm{X})$ and Resilience $(\mathrm{Y})$ is equal to 0.473 , with a significance of 0,000 . Based on the decision criteria, it is concluded that the correlation between the two variables is significant, below $0.05(0,000<0,05)$. In addition, the correlation is positive, with an increase in religiousity, and resilience.

\section{Discussion}

Several religious aspects directly increase resilience, such as the involvement of individuals in a religious community through social media platforms. The Centrality of Religiosity Scale (CRS), developed by Huber, was used to determine the five aspects of religiosity, namely intellectual dimensions, ideology, public and private practice, as well as a religious experience. Meanwhile, the Brief Resilience Scale developed by Smith, Dalen, Wiggins, Tooley, Christopher, and Bernard was used to measure resilience. The intellectual dimension shows how often zgeneration thinks about their religion. Ideology refers to beliefs or dogma in the society regarding the existence of a transcendent reality and the relationship between the transcendence and human. For example, in Islam, the belief to have one God called "Allah" and Muhammad as their prophet (Huda, 2003). Furthermore, public practice related to social expectation showed that z-generation involve in church services (Santos \& Mathews, 2001).

Private practice is prayers conducted by the zgeneration, such as sholat in Islam and meditation in Budha (Woodhead, 2011). The last is religious experience, which is the direct contact with ultimate reality. It is concluded that religiousity indicator related to two activities, involvement with the human on private practice that builds a relationship with God. These five aspects of religiousity are theoretically related to personal characteristics, social relating, coping, and health. Resilient personal characteristic refers to the positive quality of individual such as self-efficacy and empathy (Norman, 2004). These two traits are closely related to religious practice. A research carried out by Bigdeloo and Bozorgi (Bigdeloo \& Bozorgi, 2016) showed that there are positive relationships between religious attitude, selfefficacy, and life satisfaction. This is because Self-efficacy is an intellectual dimension related to the individual beliefs on their capabilities.

Religiousity is express by the involvement of the individual in religious community, this domain was significantly related to social resilience indicator. The social network is a predictor of the relationship between religion and life satisfaction. This is because the religious community serves as social support that provide friendship and companion for people (Lim and Putnam; 2010). Supratman (2017) stated that the z-generation, spend $79 \%$ of their daily time accessing the internet and utilizing social media such as line, whatsapp, and facebook. Wellman (2016) explains that the internet through social media is used to expand, simplify, and strengthen social ties. McClure (McClure, 2016) reported that social networks were able to increase the beliefs and practices of worship. This fact makes it easier for religious communities to interact and share information in order to provide emotional support when individuals experience difficulties that tend 
to affect their mental and psychological health (Reis \& Menezes, 2017).

Furthermore, individual ability to cope with stress is related to community involvement, private practice, and religious experience. Some studies stated that "religious coping" refers to individual ability to cope with daily activities. Ano \& Vasconcelles (Ano \& Vasconcelles, 2005) defined religious coping as the use of beliefs or behaviors to solve problems and alleviate negative emotional consequences of stressful life circumstances.

Several studies stated that religion and health strongly influence each other. Chatters (Chatters, 2000) reported that religions significantly shape the nature, type, and extent of social relationships, thereby, providing physical and mental health benefits. Koenig (Koenig, 2015) stated that religions and spirituality provide resources for coping with the stress, and provide sense control over events. These explanations prove how religion and resilience are related to the $\mathrm{z}$ generation.

Identification of the relationship between religiousity and resilience on $\mathrm{z}$ generation significantly contributes to the education setting. Lunenburg (2010) stated that counseling is one of the main goals used to help students to gain personal development equipment with life skills, especially plan action. Understanding religiosity and resilience help counselors to facilitate students' intervention and choices. Religiousity is considered an effective counseling tool with deep religiousity understanding. Wade and Post (Post \& Wade, 2009) stated that religious interventions are an effective adjunct to traditional counseling, which is dependent on religious commitment. The assessment level of counselors on resilience helps them in making plans. The limitation of this research is that few respondents were involved in this research and come from one university. Therefore, further research needs to be conducted using more $\mathrm{z}$ generation respondents.

\section{Conclusions}

Religiousity is significantly related to the resilience of the z-generation, which is explained by intellectual dimensions, ideology, public practice, private practice, and religious experience. It is also associated with personal characteristics, social relations, coping, and health. This understanding facilitates counselors in determining effective counseling intervention.

\section{References}

[1] Ano, G. G., \& Vasconcelles, E. B. (2005). Religious coping and psychological adjustment to stress: A meta-analysis. Journal of clinical psychology, 61(4), 461480.

[2] Bigdeloo, M., \& Bozorgi, Z. D. (2016). Relationship between the Religious Attitude, Self-Efficacy, and Life Satisfaction in High School Teachers of Mahshahr City. International Education Studies, 9(9), 58-66.

[3] Chase, J. (2016). The Religious Beliefs and Behaviors of Baby Boomers, Generation X, and the Millennials: are there still gender differences?

[4] Chatters, L. M. (2000). Religion and health: Public health research and practice. Annual review of public health, 21(1), 335-367.

[5] Csobanka, Z. E. (2016). The Z generation. Acta Educationis Generalis, 6(2), 63-76.

[6] Dwidienawati, D., \& Gandasari, D. (2018). Understanding Indonesia's generation Z. International Journal of Engineering \& Technology, 7(3), 245-253.

[7] Gaidhani, S., Arora, L., \& Sharma, B. K. (2019). Understanding the attitude of generation $\mathrm{Z}$ towards workplace. International Journal of Management, Technology And Engineering, 9, 2804-2812.

[8] Huda, Q.-u. (2003). Knowledge of allah and the islamic view of other religions. Theological Studies, 64(2), 278-305. 
[9] Javanmard, G. H. (2013). Religious beliefs and resilience in academic students. Procedia-Social and Behavioral Sciences, 84, 744-748.

[10] Koenig, H. G. (2015). Religion, spirituality, and health: A review and update. Advances in mind-body medicine, 29(3), 19-26.

[11] McClure, P. K. (2016). Faith and Facebook in a pluralistic age: The effects of social networking sites on the religious beliefs of emerging adults. Sociological Perspectives, 59(4), 818-834.

[12] Merriman, M. (2015). A new generation with unique experiences, beliefs and behaviors. They are Gen Z. London: Ernst and Young LP

[13] Nooney, J., \& Woodrum, E. (2002). Religious coping and church-based social support as predictors of mental health outcomes: Testing a conceptual model. Journal for the scientific study of religion, 41(2), 359-368.

[14] Norman, E. (2004). Resiliency enhancement: Putting the strength perspective into social work practice: Columbia university press.

[15] Novkovska, B., \& Serafimovic, G. (2018). Recognizing the vulnerability of Generation $\mathrm{Z}$ to economic and social risks. UTMS Journal of Economics, 9(1), 29-37.

[16] Oxman, T. E., Freeman, D. H., \& Manheimer, E. D. (1995). Lack of social participation or religious strength and comfort as risk factors for death after cardiac surgery in the elderly. Psychosomatic medicine, 57(1), 5-15.

[17] Post, B. C., \& Wade, N. G. (2009). Religion and spirituality in psychotherapy: A practice-friendly review of research. Journal of clinical psychology, 65(2), 131-146.

[18] Powell, L. H., Shahabi, L., \& Thoresen, C. E. (2003). Religion and spirituality:
Linkages to physical health. American psychologist, 58(1), 36.

[19] Putra, Y. S. (2016). Theoritical Review: Teori Perbedaan Generasi. Among Makarti 9 (18): 123-134.

[20] Rahmati, M., Khaledi, B., Salari, N., Bazrafshan, M.-R., \& Haydarian, A. (2017). The effects of religious and spiritual interventions on the resilience of family members of patients in the ICU. Shiraz, EMed J, 18(11), e13007.

[21] Reis, L. A. d., \& Menezes, T. M. d. O. (2017). Religiosity and spirituality as resilience strategies among long-living older adults in their daily lives. Revista Brasileira de Enfermagem, 70(4), 761-766.

[22] Salleh, M. S. M., Mahbob, N. N., \& Baharudin, N. S. (2017). Overview of" Generation Z "Behavioural Characteristic and its Effect towards Hostel Facility. International Journal of Real Estate Studies, 11(2), 59-67.

[23] Sallquist, J., Eisenberg, N., French, D. C., Purwono, U., \& Suryanti, T. A. (2010). Indonesian adolescents' spiritual and religious experiences and their longitudinal relations with socioemotional functioning. Developmental Psychology, 46(3), 699.

[24] Santos, J., \& Mathews, B. P. (2001). Quality in religious services. International journal of nonprofit and voluntary sector marketing, 6(3), 278-288.

[25] Smith, B. W., Dalen, J., Wiggins, K., Tooley, E., Christopher, P., \& Bernard, J. (2008). The brief resilience scale: assessing the ability to bounce back. International journal of behavioral medicine, 15(3), 194200.

[26] Smith, L., Webber, R., \& DeFrain, J. (2013). Spiritual well-being and its relationship to resilience in young people: A mixed 
methods case study. Sage Open, 3(2), 2158244013485582.

[27] Stavrianea, A., \& Kamenidou, I. (2017). Generation $\mathrm{Z}$ and religion in times of crisis Strategic Innovative Marketing (pp. 205211): Springer.

[28] Woodhead, L. (2011). Five concepts of religion. International review of Sociology, 21(1), 121-143. 